\title{
Preparation of Bimetallic Pd-Co Nanoparticles on Graphene Support for Use as Methanol Tolerant Oxygen Reduction Electrocatalysts
}

\author{
Ravindra Nath Singh \\ Department of Chemistry, Centre of Advanced Study \\ Banaras Hindu University, \\ Varanasi, India \\ rnsbhu@rediffmail.com
}

\author{
Chandra Shekhar Sharma \\ Department of Chemistry, Centre of Advanced Study \\ Banaras Hindu University, \\ Varanasi, India \\ shekhar3040@rediffmail.com
}

\begin{abstract}
Graphene-supported (40-x) wt\% Pd $\quad$ x wt $\%$ Co $(0 \leq x \leq 13.33)$ alloys/composites have been prepared by a microwave-assisted polyol reduction method and been investigated for their structural and electrocatalytic properties for the oxygen reduction reaction (ORR) in $0.5 \mathrm{M} \mathrm{H}_{2} \mathrm{SO}_{4}$ at 298 $\mathrm{K}$. The study demonstrated that the bimetallic Pd-Co composite nanoparticles are, in fact, alloy nanoparticles with fec crystalline structure. Partial substitution of Pd by Co (from 3.64 to 13.33 $\mathrm{wt} \%$ ) in $40 \mathrm{wt} \% \mathrm{Pd} / \mathrm{graphene}$ decreases the lattice parameter as well as the crystallite size and increases the apparent catalytic activity, the latter, however, being the greatest with $8 \mathrm{wt} \% \mathrm{Co}$. The ORR activity of the active $32 \mathrm{wt} \% \mathrm{Pd} 8 \mathrm{wt} \% \mathrm{Co}$ is found to be considerably low when it was deposited on the support multiwall carbon nanotubes under similar conditions. The rotating disk electrode study indicated that the ORR on $32 \mathrm{wt} \%$ Pd $8 \mathrm{wt} \% \mathrm{Co} / \mathrm{GNS}$ in $0.5 \mathrm{M} \mathrm{H}_{2} \mathrm{SO}_{4}$ follows approximately the four-electron pathway.
\end{abstract}

Keywords- graphene-supported composite; oxygen reduction reaction;microwave-assisted polyol reduction method; electrocatalytic properties.

\section{INTRODUCTION}

Among various direct liquid fuel cells (DLFCs), the direct methanol fuel cell (DMFC) has received the most intensive attention. Considerable improvements have been made in its performance [1-4], however, one of the main obstacles for the commercialization of DMFC is the methanol crossover from the anode to the cathode compartment through the solid polymer electrolyte membrane (SPEM) [5-6]. Platinum is the best cathode material known for the oxygen reduction reaction (ORR) due to its high work function ability to cause appreciable oxygen reduction, and good resistance to dissolution [7]. However, due to high cost and limited availability in nature, pure platinum material is not commercially viable. Also, Pt catalysts have high intrinsic activities to both ORR and MOR (methanol oxidation reaction) and therefore, the efficiency of Pt-based cathode materials decreases by the interference of oxidation of alcohol present in the cathodic compartment during the cell operation. Recently, Pd-based cathode catalysts have attracted much attention because Pd possesses properties similar to those of Pt (same group of the Periodic Table, same crystal structure, and similar atomic size) and, as similar to Pt, it has also a four electron pathway for ORR [8]. The cost of Pd is currently about onethird of $\mathrm{Pt}$ and it is, at least, 50 times more abundant than $\mathrm{Pt}$ [9]. In addition, it has negligible electrocatalytic activity towards MOR in acidic mediums [10].

Several carbon-supported Pd-based bimetallic cathode materials have already been reported [11-16]. Graphene is an allotrope of carbon (like diamond, fullerene, carbon nanotubes (CNT) etc.) having $\mathrm{sp}^{2}$-hybridized carbon atoms forming two dimensional monolayer sheets possessing high surface area [17] and excellent electronic mobility at room temperature [18-19]. Compared to other carbon supports used for obtaining active fuel cell catalysts, it is low cost and has large surface area $[17,20-21]$ and much lower production cost $[20,22]$. However, the investigation of graphene as a metal catalyst support in fuel cells is very limited. Singh and Awasthi [23] obtained $20 \mathrm{wt} \% \mathrm{Pd}$ nanoparticles dispersed on graphene nano sheets (GNS), nanocarbon powders (NC) and multiwalled carbon nanotubes (MWCNTs) and demonstrated that the electrocatalytic activity of $20 \mathrm{wt} \% \mathrm{Pd} / \mathrm{GNS}$ for methanol electrooxidation was significantly higher than that of $20 \mathrm{wt} \%$ $\mathrm{Pd} / \mathrm{MWCNTs}$ or $20 \mathrm{wt} \% \mathrm{Pd} / \mathrm{NC}$ in $1 \mathrm{M} \mathrm{KOH}+1 \mathrm{M} \mathrm{CH}_{3} \mathrm{OH}$. Recently, graphene has also been used as a support for Pt to investigate the electrocatalytic activity and durability towards the ORR. The result showed the enhanced electrocatalytic activity and durability of graphene-supported metal electrodes compared with CNT or amorphous carbon supported electrodes [24-25]. This has been attributed to the intrinsic graphitization degree of graphene and the enhanced metal catalyst-support interaction. Very recently, Rao et al. [26] synthesized graphene-supported $\mathrm{Pt}_{3} \mathrm{Co}$ and $\mathrm{Pt}_{3} \mathrm{Cr}$ alloy nanoparticles. They found the ORR activity of the $\mathrm{Pt}_{3} \mathrm{M}(\mathrm{M}=\mathrm{Co}$ and $\mathrm{Cr}) /$ graphene 3-4 times higher than that of Pt/graphene. The high catalytic performance of $\mathrm{Pt}_{3} \mathrm{M}$ alloys is ascribed to the inhibition of formation of hydroxyl species on Pt surface by alloying.

In this paper, we obtained Pd nanoparticles (NPs) dispersed on GNS for the ORR in acid solutions. Preliminary investigations showed that the $40 \mathrm{wt} \% \mathrm{Pd} / \mathrm{GNS}$ electrode has the greatest ORR activity in $0.5 \mathrm{M} \mathrm{H}_{2} \mathrm{SO}_{4}$. To enhance the 
ORR activity of the electrode further, Pd-Co bimetallic nanoparticles with varying $\mathrm{Co} / \mathrm{Pd}$ ratios (i.e. 1:10, 1:6, 1:4 and $1: 2$ ) by weight were deposited on GNS and their structural and electrocatalytic activities in Ar- and $\mathrm{O}_{2}$-saturated $0.5 \mathrm{M} \mathrm{H}_{2} \mathrm{SO}_{4}$ with and without containing methanol were investigated. The investigation of ORR, to our knowledge, has not been reported on graphene-supported Pd-based bimetallic NPs in acid solutions.

\section{EXPERIMENTAL}

\section{A. Catalyst Preparation}

Home made graphite oxide $\left(\mathrm{GO}_{\mathrm{x}}\right)$ is taken as the precursor for the preparation of GNS. $\mathrm{GO}_{\mathrm{x}}$ was prepared by a modified Hummers and Offemmans method [27-28] and reduced to GNS by the $\mathrm{NaBH}_{4}$ reduction method $[23,29]$. A known amount of GNS is dispersed into ethylene glycol, sonicated the dispersion for one hour and then added required volumes of $1.0 \mathrm{mM}$ $\mathrm{PdCl}_{2}$ (prepared in $0.05 \mathrm{M} \mathrm{HCl}$ ), and $8.4 \mathrm{mM} \mathrm{CoCl}_{2} .6 \mathrm{H}_{2} \mathrm{O}$ solutions and again sonicated the whole content for one hour for proper mixing. The mixture, so obtained, was maintained at $\mathrm{pH} 10$ using $\mathrm{KOH}$ solution, sonicated for $15 \mathrm{~min}$ and subsequently placed in a microwave oven at 800 watt for 5 min and then left overnight at room temperature. The black solid residue was separated from the mixture through ultracentrifugation, washed with acetone and finally dried in a vacuum oven $[26,33]$. The total metal $(\mathrm{Co}+\mathrm{Pd})$ loading on the graphene was $40 \mathrm{wt} \%$. Bimetallic nanoparticles prepared insitu are $36.36 \mathrm{wt} \% \mathrm{Pd} 3.64 \mathrm{wt} \% \mathrm{Co}, 34.28 \mathrm{wt} \% \mathrm{Pd} 5.72 \mathrm{wt} \%$ Co, 32 wt $\%$ Pd 8 wt $\%$ Co and 26.67 wt $\%$ Pd 13.33 wt $\%$ Co. For simplicity in representation, only ' $\%$ ' is written in place of ' $w t \%$ ' throughout the text hereafter. For comparison, $40 \%$ $\mathrm{Pd} / \mathrm{MWCNT}$ composite was also prepared under similar experimental conditions.

\section{B. Characterization of Catalyst}

X-ray diffraction (XRD) powder patterns of the electrocatalysts were recorded at the sweep rate of $3^{\circ} \mathrm{min}^{-1}$ on an X-ray diffractometer (Thermo Electron) using $\mathrm{CuK} \alpha$ as the radiation source $(\lambda=1.5418 \AA)$. Morphology of the electrocatalyst has been studied by transmission electron microscope (TEM: JEOL, JEM 2100).

\section{Electrode Preparation}

The ink was prepared by mixing $3 \mathrm{mg}$ of electrocatalyst in $600 \mu \mathrm{L}$ of the ethanol-water (2:1) mixture ultrasonically. $30 \mu \mathrm{L}$ of ink was placed on the glassy carbon electrode (GC: area = $0.5 \mathrm{~cm}^{2}$ ) and dried in air to evaporate the solvent. Then, $10 \mu \mathrm{L}$ of $1 \%$ Nafion solution (Alfa Aesar) was dropped over the dried catalyst layer to cover it. The catalyst loading on GC (metal+GNS) was $0.3 \mathrm{mg} \mathrm{cm}{ }^{-2}$ and accordingly, the metal loading was $0.12 \mathrm{mg} \mathrm{cm}^{-2}$. Pretreatment of the GC electrical contact with the catalyst overlayer and electrode mounting were carried out as described in $[31,32]$.

\section{Electrochemical Studies}

A three-electrode one-compartment Pyrex glass cell was used to carry out electrochemical investigations. The saturated calomel electrode $\left(E^{0}=0.242\right.$ V vs. SHE) and a pure Pt-foil (area $8 \mathrm{~cm}^{2}$ ), were used as the reference and auxiliary electrodes, respectively. The reference electrode was separated from the electrolyte by a bridge in order to prevent $\mathrm{Cl}^{-}$ contamination of the electrolyte. However, all potentials in this study refer to that of the reversible hydrogen electrode (RHE). Electrochemical studies namely cyclic voltammetry $(\mathrm{CV})$ and linear sweep voltammetry (LSV) were carried out by a computer controlled potentiostat/galvanostat (EG \& G PAR Model: 273A). CVs and LSVs of electrocatalysts were recorded in Ar- as well as $\mathrm{O}_{2}$-saturated $0.5 \mathrm{M} \mathrm{H}_{2} \mathrm{SO}_{4}$ solution with and without containing $1 \mathrm{M} \mathrm{CH}_{3} \mathrm{OH}$.

\section{RESULTS AND DISCUSSION}

\section{A. XRD/ SEM/TEM}

The XRD powder patterns of $40 \% \mathrm{Pd} / \mathrm{GNS}$ and $(40-\mathrm{x}) \%$ $\mathrm{Pd} \mathrm{x} \% \mathrm{Co}(0 \leq \mathrm{x} \leq 13.33)$ composite electrodes recorded between $2 \theta=20$ and $2 \theta=80^{\circ}$ are shown in Figure 1.

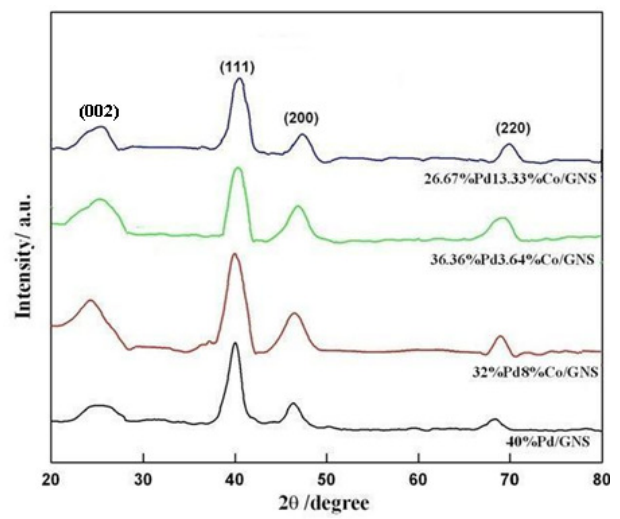

Fig. 1. XRD patterns of $\mathrm{Pd} / \mathrm{GNS}$ and $\mathrm{Pd}-\mathrm{Co} / \mathrm{GNS}$ composites.

The XRD pattern of $40 \% \mathrm{Pd} / \mathrm{GNS}$ shows the three characteristic peaks of $\mathrm{Pd}$ at $2 \theta \approx 40^{\circ}, 46.5^{\circ}$ and $68.2^{\circ}$, which correspond to planes (111), (200) and (220), respectively. Thus, $40 \% \mathrm{Pd}$ nanoparticles dispersed on GNS [23, 33] follows the fcc crystalline structure. The XRD patterns of bimetallic composites of $\mathrm{Pd}$ and $\mathrm{Co}$ also display the above three diffraction peaks but, they are found to shift slightly to a higher $2 \theta$ value with respect to the corresponding peak observed in the case of $\mathrm{Pd} / \mathrm{GNS}$ catalyst, the magnitude of shift in $2 \theta$ values being $0.5-1^{\circ}$ with $3.6-13.3 \%$ Co addition in the composite. The shift of peaks to a higher angle and the absence of reflection corresponding to Co in the XRDs of Pd-Co composites reveal the alloy formation between $\mathrm{Pd}$ and $\mathrm{Co}$, which is caused by the incorporation of $\mathrm{Co}$ in the $\mathrm{Pd}$ fcc structure. The broad peak between $2 \theta=24$ and $26^{\circ}$ is the characteristic peak corresponding to the (002) plane for graphene.

The lattice parameter $(\delta)$ and the mean crystallite size $(S)$ of Pd nanoparticles in all four catalysts have also been determined. The most intense diffraction peak of $\mathrm{Pd}$ corresponding to the plane (111) was employed to determine 
the Pd crystallite sizes $(S)$ by using the Scherrer formula. The lattice parameter was calculated by using (1):

$$
\operatorname{Sin}^{2} \theta=\frac{\lambda^{2}}{4 \delta^{2}}\left(h^{2}+k^{2}+q^{2}\right)
$$

where $\lambda$ is the $\mathrm{CuK} \alpha$ radiation wave length, $1.5418 \AA, \delta$ is the lattice parameter and $h, k, q$ are the lattice index parameters [34]. Estimates of $S$ and $\delta$ for Pd are $\sim 5.7 \mathrm{~nm}$ and $0.390 \mathrm{~nm}$, $\sim 3.7 \mathrm{~nm}$ and $0.389 \mathrm{~nm}, \sim 3.6 \mathrm{~nm}$ and $0.387 \mathrm{~nm}$, and $\sim 3.4 \mathrm{~nm}$ and $0.385 \mathrm{~nm}$ in $40 \% \mathrm{Pd} / \mathrm{GNS}, 36.36 \% \mathrm{Pd} 3.64 \% \mathrm{Co} / \mathrm{GNS}$, $32 \% \mathrm{Pd} \quad 8 \% \mathrm{Co} / \mathrm{GNS}$ and $26.27 \%$ Pd $13.33 \% \mathrm{Co} / \mathrm{GNS}$ respectively. Thus, results show that as the Co content increases in Pd-Co alloy, both the mean crystallite size $[11,16]$ and the lattice parameters $[11,34]$ decrease. The decrease in value of the lattice parameter might result from a lattice contraction upon alloying [11].

Studies of XRD and Raman spectroscopy [23] and SEM/TEM [30] of GNS used in this investigation have already been reported in our previous communication. SEM/TEM images exhibited wrinkled and folded features for graphene. Results of TEM, XRD and Raman spectroscopy showed the formation of three-layer graphene [23]. TEM images of $40 \%$ $\mathrm{Pd} / \mathrm{GNS}, 26.67 \% \mathrm{Pd} 13.33 \% \mathrm{Co} / \mathrm{GNS}$ and $32 \% \mathrm{Pd} 8 \%$ $\mathrm{Co} / \mathrm{GNS}$ are depicted in Figure 2(a-f). These figures show good dispersion of Pd and Pd-Co particles on GNS. At some places, however, there are also some concentrated regions which may be due to presence of functional groups on the GNS in significant amount [35]. Some dark contrast within the pictures are also seen which probably may be due to bragg orientation of metal particles. There is also possibility of overdeposition of metal nanoparticles which may cause mass contrast. The average particles size measured by TEM pictures of $40 \%$ $\mathrm{Pd} / \mathrm{GNS}, 26.67 \% \mathrm{Pd} 13.33 \% \mathrm{Co} / \mathrm{GNS}$ and $32 \% \mathrm{Pd} 8 \%$ $\mathrm{Co} / \mathrm{GNS}$ were $\sim 6.3, \sim 4.3$ and $\sim 4.8 \mathrm{~nm}$, respectively, which are close to values of the crystallite size obtained from the XRD study.

\section{B. Cyclic Voltammetry $(\mathrm{CV})$}

CVs of $(40-x) \% \mathrm{Pd} \mathrm{x} \% \mathrm{Co} / \mathrm{GNS}(0 \leq \mathrm{x} \leq 13.33)$ composites have been recorded at the scan rate (v) of $50 \mathrm{mV} \mathrm{s}^{-1}$ in the potential region from -0.058 to $+1.542 \mathrm{~V}$ vs. RHE in $0.5 \mathrm{M}$ $\mathrm{H}_{2} \mathrm{SO}_{4}$ with and without containing methanol at $298 \mathrm{~K}$. CVs were recorded under Ar-saturated electrolyte conditions and reproduced in Figures 3 and 4.

Features of curves shown in Figs. 3 and 4 are similar, regardless of the nature of the electrode and electrolyte. Therefore for simplicity in representation, only three representative curves for the electrocatalysts , namely $40 \%$ $\mathrm{Pd} / \mathrm{GNS}, 32 \% \mathrm{Pd} 8 \% \mathrm{Co} / \mathrm{GNS}$ and $26.67 \% \mathrm{Pd} 13.33 \%$ $\mathrm{Co} / \mathrm{GNS}$ are shown in Figures 3 and 4.

Figure 3 gathers $\mathrm{CVs}$ of $40 \% \mathrm{Pd} / \mathrm{GNS}, 32 \% \mathrm{Pd} 8 \%$ $\mathrm{Co} / \mathrm{GNS}$ and $26.67 \% \mathrm{Pd} 13.33 \% \mathrm{Co} / \mathrm{GNS}$ electrodes in $\mathrm{Ar}-$ saturated $0.5 \mathrm{M} \mathrm{H} \mathrm{H}_{2} \mathrm{SO}_{4}$. The oxidation-reduction peaks observed in the potential region, from 0.342 to $-0.058 \mathrm{~V}$ vs. RHE, are produced due to the adsorption/desorption of hydrogen [36]. The wave-like shape of voltammograms on the positive-going scan and prior to the commencement of $\mathrm{O}_{2}$ evolution reaction can be ascribed to a slow electrochemical oxidation of the palladium surface into palladium (II) oxide [37]. A relatively strong cathodic peak observed at $\mathrm{E}=0.556-$ $0.615 \mathrm{~V}$ vs. RHE on the negative-going scan is caused due to the reduction of palladium (II) oxide, formed under anodic condition, into palladium metal $[23,33,34,38]$. The relatively larger anodic peak, observed in the potential range between $0.058 \mathrm{~V}$ and $0.342 \mathrm{~V}$ vs. RHE, for the $\mathrm{Pd} / \mathrm{GNS}$ catalyst in comparison with those for $\mathrm{Pd}-\mathrm{Co} / \mathrm{GNS}$ catalysts (Figure 3) might indicate the dissolution of adsorbed hydrogen into bulk $\mathrm{Pd}$. The addition of Co within the catalyst might restrain dissolution of hydrogen into bulk $\mathrm{Pd}-\mathrm{Co} / \mathrm{GNS}$ as compared to pure Pd catalyst [10].

It is known that unlike $\mathrm{Pt}$, the bulk $\mathrm{Pd}$ can absorb hydrogen [38] and so, the charge of a monolayer of adsorbed hydrogen is difficult to determine in the case of Pd. Therefore, the electrochemically active surface areas (EASAs) of the $\mathrm{PdCo} / \mathrm{GNS}$ composite electrodes have been measured by determining the coulombic charge $(\mathrm{Q} / \mathrm{mC})$ for the reduction of palladium oxide [30, 38]. Q has been determined by integrating the oxide reduction peak. The EASA of the electrode was then estimated using the relation $\mathrm{EASA}=\mathrm{Q}(\mathrm{mC}) / \mathrm{S}\left(\mathrm{mC} \mathrm{cm}^{-2}\right)$, where $\mathrm{S}$ is the proportionality constant. A charge value of 0.405 $\mathrm{mC} \mathrm{cm}$ is assumed for reduction of PdO monolayer [23, 30, $33,39]$. The EASA values of catalysts (in ' $\mathrm{cm}^{2}$ ), thus estimated, are listed in Table 1.

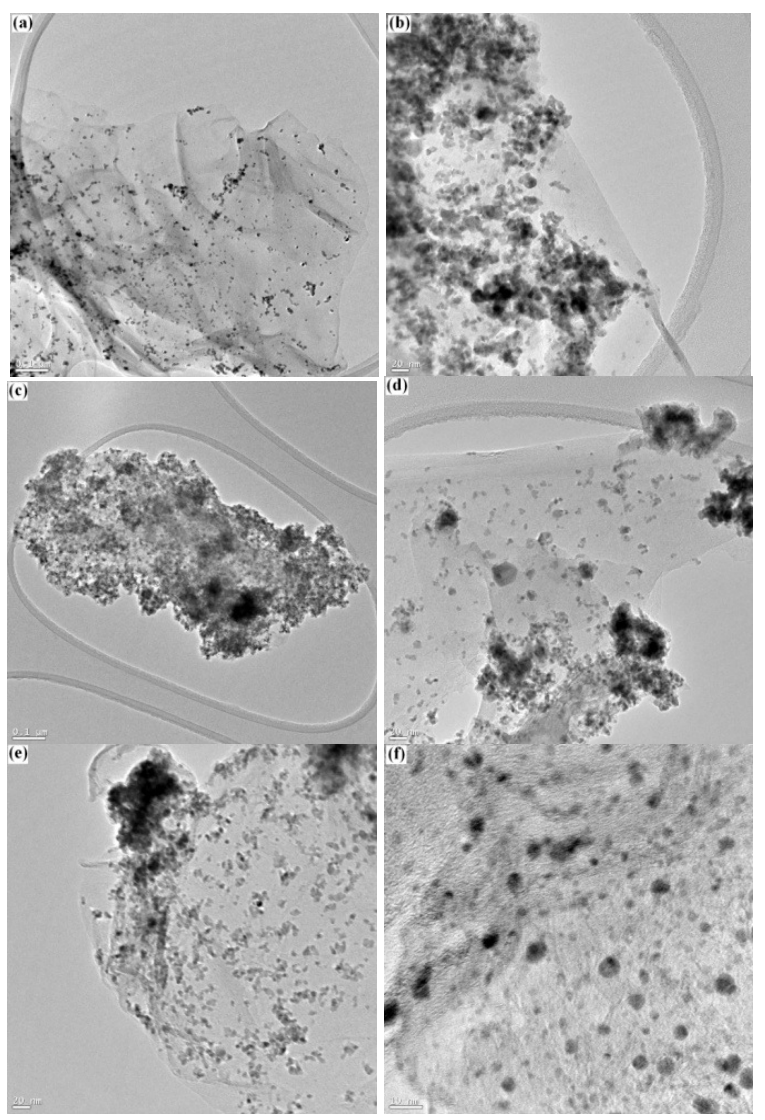

Fig. 2. TEM images of $40 \% \mathrm{Pd} / \mathrm{GNS}$ (a and b), $26.67 \% \mathrm{Pd} 13.33 \%$ $\mathrm{Co} / \mathrm{GNS}$ (c and d) and 32\% Pd $8 \% \mathrm{Co} / \mathrm{GNS}$ (e and f). 


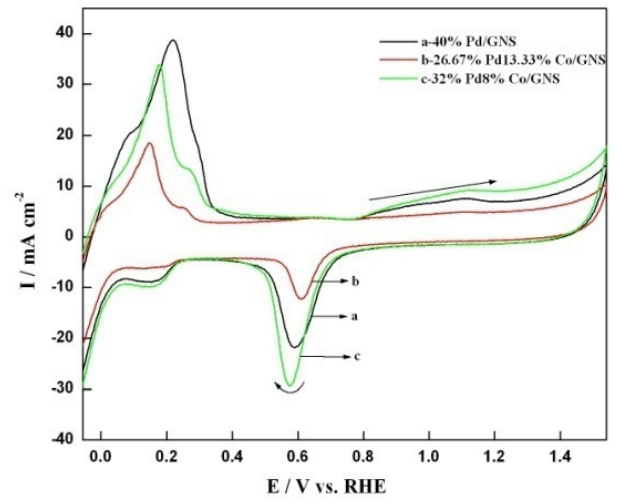

Fig. 3. Cyclic Voltammograms of $\mathrm{Pd} / \mathrm{GNS}$ and $\mathrm{PdCo} / \mathrm{GNS}$ composites in Ar-saturated $0.5 \mathrm{M} \mathrm{H}_{2} \mathrm{SO}_{4}$. Scan rate $=50 \mathrm{mVs}^{-1} \& \mathrm{~T}=298 \mathrm{~K}$.

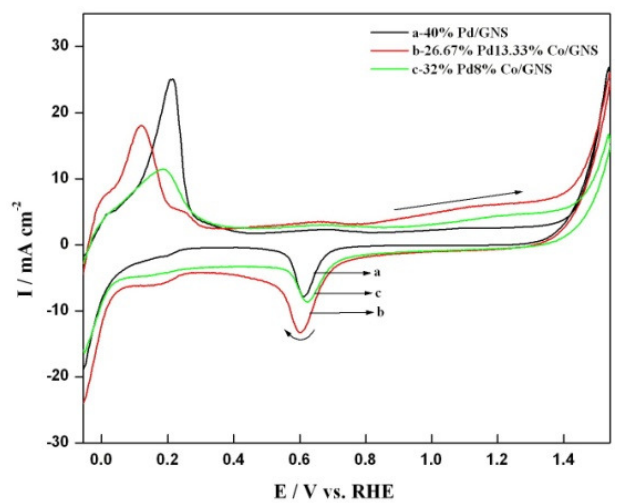

Fig. 4. Cyclic Voltammograms of $\mathrm{Pd} / \mathrm{GNS}$ and $\mathrm{PdCo} / \mathrm{GNS}$ composites in Ar saturated $0.5 \mathrm{M} \mathrm{H}_{2} \mathrm{SO}_{4} 1 \mathrm{M} \mathrm{CH}_{3} \mathrm{OH}$. Scan rate $=50 \mathrm{mVs}^{-1} \& \mathrm{~T}=298 \mathrm{~K}$.

TABLE I. ELECTROCATALYTIC PROPERTIES OF (40-x)\% Pd $\mathrm{x} \% \quad \mathrm{Co}$ NANOPARTICLES DISPERSED ON GNS in $0.5 \mathrm{M} \mathrm{H}_{2} \mathrm{SO}_{4}$; GEOMETRICAL AREA OF THE ELECTRODE $=0.5 \mathrm{~cm}^{2}$; METAL LOADING $(\mathrm{L})=0.12 \mathrm{mg} \mathrm{cm}^{-2}$, TEMP. $298 \mathrm{~K}$.

\begin{tabular}{|c|c|c|c|c|c|c|c|c|}
\hline \multirow{2}{*}{$\frac{e^{0}}{e^{2}}$} & \multicolumn{2}{|c|}{ 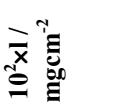 } & \multirow{2}{*}{$\frac{U}{0}$} & \multicolumn{2}{|l|}{ 芯 } & \multicolumn{2}{|c|}{$\begin{array}{c}\text { Apparent } \\
\text { current at } \\
\mathrm{E}=0.20 \mathrm{~V} /\end{array}$} & \multirow{2}{*}{ 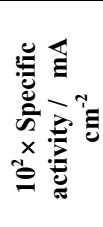 } \\
\hline & $P d$ & Co & & $\mathrm{E}$ & $\tilde{5}$ & $\underset{\Xi}{\Xi}$ & $\underset{\Xi}{\Xi}$ & \\
\hline 0 & 12 & 0 & 16 & 39.5 & 658 & 0.33 & 5.5 & 0.84 \\
\hline 3.64 & 10.9 & 1.1 & 18 & 44.4 & 823 & 0.53 & 9.8 & 1.19 \\
\hline 5.72 & 10.3 & 1.7 & 19 & 46.9 & 920 & 0.71 & 13.9 & 1.51 \\
\hline 8.00 & 9.6 & 2.4 & 23 & 56.8 & 1183 & 0.79 & 16.4 & 1.39 \\
\hline 13.33 & 8.0 & 4.0 & 6 & 14.8 & 380 & 0.42 & 10.7 & 2.83 \\
\hline
\end{tabular}

The observed EASA of a particular electrocatalyst has also been normalized with respect to the actual Pd mass taken in that electrocatalyst. Based on values of the EASA, the catalysts investigated follow the order:

$32 \% \mathrm{Pd} 8 \% \mathrm{Co} / \mathrm{GNS}>34.28 \% \mathrm{Pd} 5.72 \% \mathrm{Co} / \mathrm{GNS}>36.36 \%$ $\mathrm{Pd} 3.64 \% \mathrm{Co} / \mathrm{GNS}>40 \% \mathrm{Pd} / \mathrm{GNS}>26.67 \% \mathrm{Pd} 13.33 \%$ $\mathrm{Co} / \mathrm{GNS}$
Features of $\mathrm{CVs}$ of $\mathrm{Pd}-\mathrm{Co} / \mathrm{GNS}$ composites recorded in Arsaturated $0.5 \mathrm{M} \mathrm{H}_{2} \mathrm{SO}_{4}$ containing $1 \mathrm{M} \mathrm{CH}_{3} \mathrm{OH}$ shown in Figure 4 are also similar to those recorded in absence of methanol under similar experimental conditions (Figure 3); they do not show any characteristic current peak for the electrooxidation of alcohol. Thus, results show that Pd-Co bimetallic composites are perfectly immune to the MOR in acid solutions and can be used as methanol tolerant reduction reaction electrocatalysts.

\section{Electrocatalytic Activity}

Linear sweep voltammetries (LSVs) of $(40-\mathrm{x}) \% \mathrm{Pd} \mathrm{x} \%$ $\mathrm{Co} / \mathrm{GNS}(0 \leq \mathrm{x} \leq 13.33)$ composites have been recorded in the potential region from +0.842 to $+0.042 \mathrm{~V}$ vs. RHE at the scan rate $(\mathrm{v})$ of $5 \mathrm{mV} \mathrm{s}^{-1}$ in $\mathrm{Ar}$ - and $\mathrm{O}_{2}$ - saturated $0.5 \mathrm{M} \mathrm{H}_{2} \mathrm{SO}_{4}$ at 298 K. Curves, so obtained, are reproduced in Figure 5.

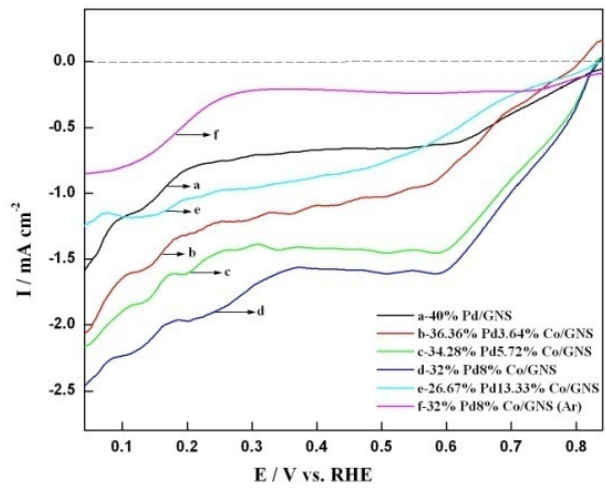

Fig. 5. Linear Scan Voltammograms of $\mathrm{Pd} / \mathrm{GNS}$ and $\mathrm{PdCo} / \mathrm{GNS}$ in $\mathrm{O}_{2}$ saturated $0.5 \mathrm{M} \mathrm{H}_{2} \mathrm{SO}_{4}$. Scan rate $=5 \mathrm{mVs}^{-1} \& \mathrm{~T}=298 \mathrm{~K}$.

LSVs of electrocatalysts in Ar-saturated $0.5 \mathrm{M} \mathrm{H}_{2} \mathrm{SO}_{4}$ were similar and seem to have very little (i.e. negligible) current contributions towards the electroreduction of oxygen. A typical LSV curve for the $32 \% \mathrm{Pd} 8 \% \mathrm{Co} / \mathrm{GNS}$ catalyst in Ar-saturated $0.5 \mathrm{M} \mathrm{H}_{2} \mathrm{SO}_{4}$ is shown in Figure 5. Voltammograms in $\mathrm{O}_{2}-$ saturated solution depicted in Figure 5 show that among the bimetallic Pd-Co composites, the $32 \%$ Pd $8 \%$ Co/GNS electrode is the greatest active while the $26.67 \% \mathrm{Pd} 13.33 \% \mathrm{Co}$ is the least active electrode for the ORR. Based on values of the ORR current density noted from Figure 5 at a constant potential, $\mathrm{E}=0.442 \mathrm{~V}$ vs. RHE, different electrocatalysts can be put in the activity order:

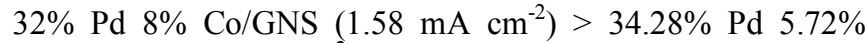
$\mathrm{Co} / \mathrm{GNS}\left(1.42 \mathrm{~mA} \mathrm{~cm}{ }^{-2}\right)>36.36 \% \mathrm{Pd} 3.64 \% \mathrm{Co} / \mathrm{GNS}(1.06$ $\left.\mathrm{mA} \mathrm{cm}{ }^{-2}\right)>26.67 \%$ Pd $13.33 \% \mathrm{Co} / \mathrm{GNS}\left(0.84 \mathrm{~mA} \mathrm{~cm}^{-2}\right)>$ $40 \% \mathrm{Pd} / \mathrm{GNS}\left(0.66 \mathrm{~mA} \mathrm{~cm}^{-2}\right)$.

The enhanced catalytic activities observed in the case of Pd-Co composites in comparison with pure $\mathrm{Pd}$ may be attributed to the alloying of $\mathrm{Pd}$ and Co followed by a lattice compression (i.e. reduction in Pd-Co bond). The lattice compression results in shift of d-band center, which has an effect on surface activity of Pd sites. It has already been shown by DFT calculation that the compression of a Pd lattice in alloy produces the downshift of the d-band center energy [40]. The 
increase in the specific activity of the electrode with Co introduction for $\mathrm{Pd}$ shown in Table 1 also indicates modification in the electronic properties of the electrode material in favour of electrocatalysis of the ORR. The decrease in the apparent ORR activity at the higher Co addition $(13.33 \%)$ can be ascribed to somewhat lowering of percentage of Pd in the bimetallic alloy. Also, blocking of some active Pd sites at higher Co additions cannot be ruled out.

To examine the influence of the catalyst support, the $32 \%$ Pd 8\% Co alloy nanoparticles were also obtained on MWCNTs and investigated as electrocatalyst for the ORR under similar experimental conditions as employed in the study of the same alloy catalyst obtained on the GNS support. LSV curves shown in Figure 6 indicate that the ORR performance of the Pd-Co alloy is greatly improved when obtained on the GNS support rather than on MWCNTs. Also, the onset of the reduction wave gets shifted toward the higher positive potential (Figure 6), which can be ascribed to greatly enlarged geometrical surface area and better electron transport properties of the GNS support.

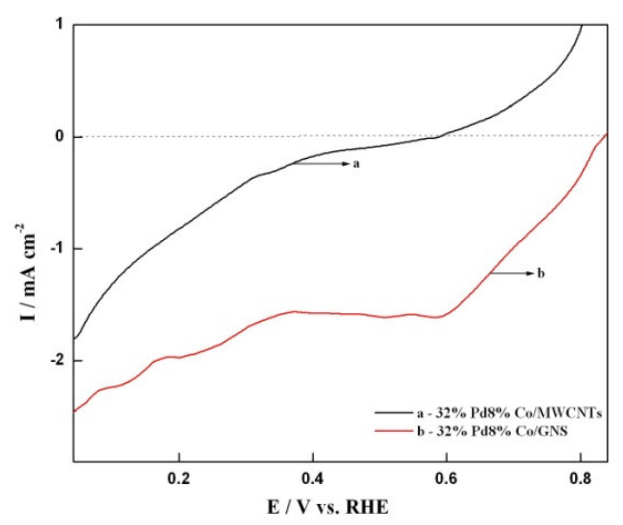

Fig. 6. Linear Scan Voltammograms of $32 \%$ Pd $8 \%$ Co supported on GNS and MWCNTs in $\mathrm{O}_{2}$-saturated $0.5 \mathrm{M} \mathrm{H}_{2} \mathrm{SO}_{4}$. Scan rate $=5 \mathrm{mVs}^{-1} \& \mathrm{~T}=$ $298 \mathrm{~K}$.

The most active bimetallic catalyst, $32 \% \mathrm{Pd} 8 \% \mathrm{Co} / \mathrm{GNS}$, of the investigation was also deposited at the disk (dia. $0.3 \mathrm{~cm}$ ) of a rotating disk electrode (RDE) and LSV curves at the slow scan rate of $2 \mathrm{mV} \mathrm{s}^{-1}$ and varying rotations were recorded in $\mathrm{O}_{2}$ - saturated $0.5 \mathrm{M} \mathrm{H}_{2} \mathrm{SO}_{4}$ at $298 \mathrm{~K}$. LSV curves, so obtained, are shown in Figure 7. The observation of LSV curves of the electrode at varying rotations indicates that at the higher potential region the ORR is a mixed diffusion-kinetic controlled process. Therefore, the overall measured disk current density $(j)$ was determined by using the relation [4142],

$$
\frac{1}{j}=\frac{1}{j_{k}}+\frac{1}{j_{d}}
$$

where $j_{k}$ and $j_{d}$ represent the currents, controlled by electron transfer kinetics and mass transport (mainly diffusion) properties, respectively.

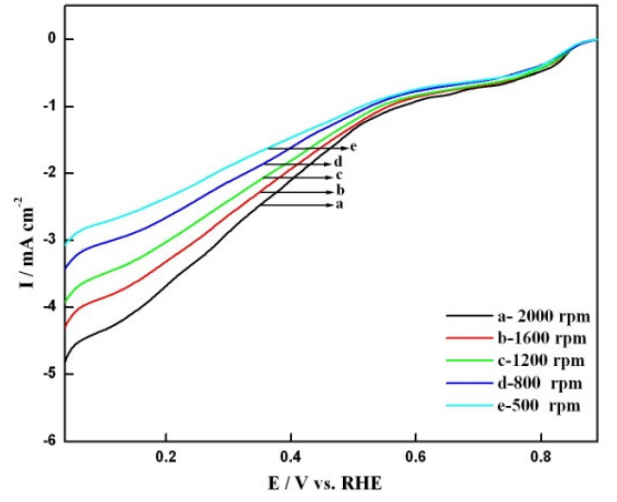

Fig. 7. Linear scan voltammograms of $32 \% \mathrm{Pd} 8 \% \mathrm{Co} / \mathrm{GNS}$ at varying rotations in $\mathrm{O}_{2}$-saturated $0.5 \mathrm{M} \mathrm{H}_{2} \mathrm{SO}_{4}$; scan rate $=2 \mathrm{mVs}^{-1} ; \& \mathrm{~T}=298 \mathrm{~K}$.

The analysis of catalytic current as a function of rotation rate was done with the help of the Koutecky-Levich relation [43]:

$$
\frac{1}{j}=\frac{1}{j_{k}}+\frac{1}{B \omega^{1 / 2}}
$$

where $\omega$ is the electrode rotation in revolutions per minute (rpm) and $B$ is the Levich constant given by [44]:

$$
B=\frac{1}{0.2 n F C_{O_{2}} D_{O_{2}}^{2 / 3} v^{-1 / 6}}
$$

where 0.2 is a constant, $\mathrm{C}_{\mathrm{O} 2}$ is the concentration of $\mathrm{O}_{2}$ dissolved in the bulk electrolyte, $n$ is the number of electrons transferred per molecule of $\mathrm{O}_{2}$ reduced, $F$ is the Faraday constant, $D_{\mathrm{O}_{2}}$ is the diffusion coefficient of oxygen in solution, $v$ is the kinematic viscosity of sulphuric acid.

The kinetic values, with respect to activation and diffusion, have been calculated by constructing the linear KouteckyLevich, L-K, (i.e. $1 / j$ versus $1 / \omega^{1 / 2}$ ) plots at different constant potentials, as shown in Figure 8 , and measuring the intercept $\left(1 / j=1 / j_{k}\right.$ for $\left.1 / \omega^{1 / 2}=0\right)$ and slope $(=1 / B)$ of these linear curves. Values of $j_{k}$ and $B$, so obtained, are listed in Table 2 .

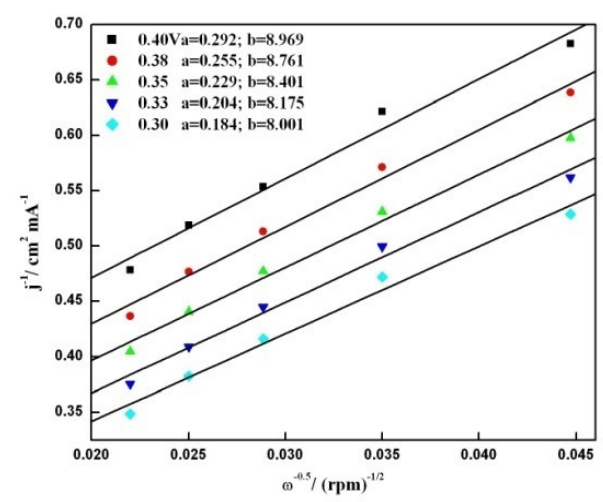

Fig. 8. $\quad 1 / \mathrm{j}$ versus $1 / \omega^{1 / 2}$ plots constructed from Fig.7 at constant potentials. 
Values of slope listed in Table 2 seem to slightly decrease with the increase of the cathodic overpotential; the average value of the slope being $8.44 \pm 0.45 \times 10^{-2} \mathrm{~mA}^{-1} \mathrm{~cm}^{2} \mathrm{rpm}^{1 / 2}$ in the potential range, $0.4-0.3 \mathrm{~V}$ vs. RHE. The average slope, thus determined, is somewhat lower than the theoretical slope, 9.41 $\mathrm{x} 10^{-2} \mathrm{~mA}^{-1} \mathrm{~cm}^{2} \mathrm{rpm}^{1 / 2}$ [44]. The theoretical slope was computed by using (5) and considering $n=4, F=96485$ coulomb, $C_{O 2}=1.1 \times 10^{-6} \mathrm{~mol} \mathrm{~cm} \mathrm{~cm}^{-3}, D_{O 2}=1.4 \times 10^{-5} \mathrm{~cm}^{2} \mathrm{~s}^{-1}$, $v=1.0 \times 10^{-2} \mathrm{~cm}^{2} \mathrm{~s}^{-1}$, electrolyte $=0.5 \mathrm{M} \mathrm{H}_{2} \mathrm{SO}_{4}$. Thus, the result shows that the ORR in $0.5 \mathrm{M} \mathrm{H}_{2} \mathrm{SO}_{4}$ follows an $3.6(\approx 4)$ electron pathway in the potential region, $0.30-0.40 \mathrm{~V}$ vs. RHE. Zhang et al [45] also found similar parallel straight lines for K$\mathrm{L}$ plots indicating four-electron reduction of $\mathrm{O}_{2}$ on $\mathrm{Pt} / \mathrm{Pd}$ (111) surface in $0.1 \mathrm{M} \mathrm{HClO}_{4}$. Recent studies of ORR on $\mathrm{Pd}_{0.5} \mathrm{Ni}_{\mathrm{X}} \mathrm{Se}_{(0.5-\mathrm{x})}$ [46], $\mathrm{Pd}$ deposited on porous carbon paper [47], $\mathrm{IrCo} / \mathrm{C}$ [44] and $\mathrm{Pd}$ nanoparticles/MWCNTs [48] in $\mathrm{H}_{2} \mathrm{SO}_{4}$ solution also exhibited a four-electron charge transfer pathway for electroreduction of $\mathrm{O}_{2}$ to $\mathrm{H}_{2} \mathrm{O}$.

TABLE II. ESTIMATE OF KINETIC VALUES FOR ORR AT THE CATALYTIC FILM OF $32 \%$ Pd $8 \%$ Co/GNS ON GLASSY CARBON DISK $(0.3 \mathrm{~cm}$ DIA.) IN $0.5 \mathrm{M}$ $\mathrm{H}_{2} \mathrm{SO}_{4}$; SCAN RATE $: 2 \mathrm{mV} \mathrm{s}^{-1}$, ROTATION SPEED :1600 RPM TEMP. $298 \mathrm{~K}$.

\begin{tabular}{|c|c|c|c|c|}
\hline E/V & $j_{k} / \mathbf{m A ~} \mathbf{c m}^{-2}$ & slope & $B / \mathrm{mA} \mathrm{cm}^{-2} \mathrm{rpm}^{-1 / 2}$ & $\begin{array}{c}j_{d}\left(=B \omega^{1 / 2}\right) / \\
\mathbf{m A ~} \mathrm{cm}^{-2}\end{array}$ \\
\hline 0.40 & 3.42 & 8.9 & 0.112 & 4.48 \\
\hline 0.38 & 3.92 & 8.8 & 0.114 & 4.56 \\
\hline 0.35 & 4.37 & 8.4 & 0.119 & 4.76 \\
\hline 0.33 & 4.90 & 8.1 & 0.123 & 4.92 \\
\hline 0.30 & 5.43 & 8.0 & 0.125 & 5.00 \\
\hline
\end{tabular}

\section{CONCLUSION}

The study shows that incorporation of Co into Pd produces a solid solution (i.e. alloy) with reduced lattice parameter as well as the particle size. All the alloy catalysts exhibited better electrocatalytic performance than the pure Pd catalyst, the ORR activity, however, being the greatest with $32 \% \mathrm{Pd} 8 \% \mathrm{Co} / \mathrm{GNS}$ catalyst. It is worth-mentioning that all the Pd-Co bimetallic catalysts of the present investigation are good methanol tolerant cathodes. Further, the graphene displays much superior performance compared to MWCNTs as a metal catalyst support material.

\section{ACKNOWLEDGEMENT}

The financial support received, to carry out the investigation, from the Council of Scientific and Industrial Research (CSIR), Government of India through research grants (Ref. No. 01(2320)/09-EMR-II) is gratefully acknowledged. Authors thank Dr. Divesh N. Srivastava, Central Salt \& Marine Chemicals Research Institute, Bhavnagar (India) and Prof. R. S. Tiwari, Physics Department, B.H.U. (India) for recording and interpreting TEM photographs, respectively.

\section{REFERENCES}

[1] W. Quian, D. P. Wilkinson, J. Shen, H. Wang, J. Zhang, "Architecture for portable direct liquid fuel cells", J. Power Sources, Vol. 154, No. 1, pp. 202-213, 2006

[2] L. Colmenares, Z. Jusys, R. J. Behm, "Activity selectivity and methanol tolerance of Se-modified Ru/C cathode catalysts", J. Phys. Chem. C, Vol. 111, No. 3, pp. 1273-1283, 2007
[3] G. Zehl, P. Bogdanoff, I. Dorbandt, S. Fiechter, K. Wippermann, C. Hartnig, "Carbon supported Ru-Se as methanol tolerant catalysts for DMFC cathodes. Part I: Preparation and characterization of catalysts", J. Appl. Electrochem., Vol. 37, No. 12, pp. 1475-1484, 2007

[4] V. Baglio, A. Di Blasi, C. D'Urso, V. Antonucci, A. S. Arico, R. Ornelas, D. Morales-Acosta, J. Ledesma-Garcia, L. A. Godinez, L. G. Arriaga, L. Alvarez-Contreras, "Development of Pt and Pt-Fe catalysts supported on multiwalled carbon nanotubes for oxygen reduction in direct methanol fuel cell applications", J. Electrochem. Soc., Vol. 155, No. 8, pp. B829-B833, 2008

[5] A. S. Arico, S. Srinivasan, V. Antonucci, "DMFCs: from fundamental aspects to technology development", Fuel Cells, Vol. 1, No. 2, 133-161, 2001

[6] C. Lamy, A. Lima, V. LeRhun, F. Delime, C. Contaceau, J. M. Leger, "Recent advances in the development of direct alcohol fuel cells (DAFC)”, J. Power Sources, Vol. 105, No. 2, pp. 283-296, 2002

[7] J. J. Lingane, "Chronopotentiometry study of oxygen at platinum wire electrode", J. Electronal. Chem., Vol. 2, No. 4, pp. 296-309, 1961

[8] G. F. Alvarez, M. Mamlouk, K. Scott, "An investigation of palladium oxygen reduction catalysts for the direct methanol fuel cell", Int. J. Electrochem., Article ID 684535, 2011

[9] F. Kadirgan, S. Beyhan, T. Atilan, "Preparation and characterization of nano-sized Pt-Pd/C catalysts and comparison of their electro-activity toward methanol and ethanol oxidation", Int. J. Hydrogen Energy, Vol. 34, No. 10, pp. 4312-4320, 2009

[10] K. Lee, O. Savadogo, A. Ishihara, S. Mitsushima, N. Kamiya, K. I. Ota. "Methanol-tolerant oxygen reduction electrocatalysts based on Pd-3D transition metal alloys for direct methanol fuel cell", J. Electrochem. Soc. Vol. 153, No.1, pp. A20-A24, 2006

[11] W. Wang, D. Zheng, C. Du, Z. Zou, X. Zhang, B. Xia, H. Yang, D.L. Akins, "Carbon-supported Pd-Co bimetallic nanoparticles as electrocatalysts for the oxygen reduction reaction", J. Power Sources, Vol. 167, No. 2, pp. 243-249, 2007

[12] D. S. Kim, T. J. Kim, J. H. Kim, E. F. Abo Zeid, Y. T. Kim, "Fine structure effect of PdCo electrocatalyst for oxygen reduction reaction activity: based on X-ray absorption spectroscopy studies with synchrotron beam", J. Electrochem. Sci. and Technol., Vol. 1, No. 1, pp. $31-38,2010$

[13] J. L. Fernandez, V. Raghuveer, A. Manthiram, A. J. Bard, "Pd-Ti and $\mathrm{Pd}-\mathrm{Co}-\mathrm{Au}$ electrocatalysts as a replacement for platinum for oxygen reduction in proton exchange membrane fuel cells", J. Am. Chem. Soc., Vol. 127, No. 38, pp. 13100-13101, 2005

[14] D. Wang, H. L. Xin, Y. Yu, H. Wang, E. Rus, D. A. Muller, H. D. Abruna, "Pt-decorated $\mathrm{PdCo} @ \mathrm{Pd} / \mathrm{C}$ core-shell nanoparticles with enhanced stability and electrocatalytic activity for the oxygen reduction reaction", J. Am. Chem. Soc., Vol. 132, No. 50, pp. 17664-17666, 2010

[15] V. D. Noto, E. Negro, S. Lavina, S. Gross, G. Pace, "Pd-Co carbonnitride electrocatalysts for polymer electrolyte fuel cells", Electrochim. Acta, Vol. 53, No. 4, pp. 1604-1617, 2007

[16] X. Li, Q. Huang, Z. Zou, B. Xia, H. Yang, "Low temperature preparation of carbon-supported Pd-Co alloy electrocatalysts for methanol-tolerant oxygen reduction reaction", Electrochim. Acta, Vol. 53, No. 22, pp. 6662-6667, 2008

[17] D. A. Dikin, S. Stankovich, E. J. Zimney, R. D. Piner, G. H.B. Dommett, G. Evmeneko, S. T. Nguyen, R. S. Ruoff, "Preparation and characterization of graphene oxide paper", Nature, Vol. 448, pp. 457460,2007

[18] K. S. Novoselov, A. K. Geim, S. V. Morozov, D. Jiang, M. I. Katsnelson, I. V. Grigorieva, S. V. Dubonos, A. A. Firsov, "Two-dimensional gas of massless Dirac fermions in graphene", Nature, Vol. 438, pp. 197-200, 2005

[19] K. S. Novoselov, A. K. Geim, S. V. Morozov, D. Jiang, Y. Zhang, S. V. Dubonos, I. V. Grigorieva, A. A. Firsov, "Electric field effect in atomically thin carbon films", Science, Vol. 306 , No. 5696, pp. 666669,2004 
[20] S. Stankovich, D. A. Dikin, G. H. B. Dommett, K. M. Kohlhaas, E. J. Zimney, E. A. Stach, R. D. Piner, S. T. Nguyen, R. S. Ruoff, "Graphenebased composite materials", Nature, Vol. 442, pp. 282-286, 2006

[21] S. Niyogi, E. Bekyarova, M. E. Itkis, J. L. McWilliams, M. A. Hamon, R. C. Haddon, "Solution properties of graphite and graphene", J. Am. Chem. Soc., Vol. 128, No. 24, pp. 7720-7721, 2006

[22] Y. Xu, H. Bai, G. Lu, C. Li, G. Shi, "Flexible graphene films via the filtration of water-soluble noncovalent functionalized graphene sheets", J. Am. Chem. Soc., Vol. 130, No. 18, pp. 5856-5857, 2008

[23] R. N. Singh, R. Awasthi, "Graphene support for enhanced electrocatalytic activity of Pd for alcohol oxidation", Catal. Sci. Technol., Vol. 1, pp. 778-783, 2011

[24] R. Kou, Y. Shao, D. Wang, M. H. Engelhard, J. H. Kwak, J. Wang, V. V. Viswanathan, C. Wang, Y. Lin, Y. Wang, I. A. Aksay, J. Liu, "Enhanced activity and stability of Pt catalysts on functionalized graphene sheets for electrocatalytic oxygen reduction reaction", Electrochem. Commun., Vol. 11, pp. 954-957, 2009

[25] Y. Shao, S. Zhang, C. Wang, Z. Nie, J. Liu, Y. Wang, Y. Lin, "Highly durable graphene nanoplatelets supported Pt nanocatalysts for oxygen reduction", J. Power Sources, Vol. 195, No. 15, pp. 4600-4605, 2010

[26] C. V. Rao, A. L. M. Reddy, Y. Ishikawa, P. M. Ajayan, "Synthesis and electrocatalytic oxygen reduction activity of graphene-supported $\mathrm{Pt}_{3} \mathrm{Co}$ and $\mathrm{Pt}_{3} \mathrm{Cr}$ alloy nanoparticles", Carbon, Vol. 49, No. 3, pp. 931-936, 2011

[27] W. S. Hummers Jr, R. E. Offeman, "Preparation of Graphitic oxide", J. Am. Chem. Soc., Vol. 80, No. 6, p. 1339, 1958

[28] L. J. Cote, F. Kim, J. Huang, "Langmuir-blodgett assembly of graphite oxide single layers", J. Am. Chem. Soc. Vol. 131, No. 3, pp. 1043-1049, 2009

[29] J. Shen, Y. Hu, M. Shi, X. Lu, C. Qin, C. Li, M. Ye, "Fast and facile preparation of graphene oxide and reduced graphene oxide nanoplatelets", Chem. Mater., Vol. 21, No. 15, pp. 3514-3520, 2009

[30] R. Awasthi, R. N. Singh, "Optimization of the Pd-Sn-GNS nanocomposite for enhanced electrooxidation of methanol", Int. J. Hydrogen Energy, Vol. 37, No. 3, pp. 2103-2110, 2012

[31] R. N. Singh, A. Singh, Anindita, "Electrocatalytic activity of binary and ternary composite films of Pd, MWCNT, and Ni for ethanol electrooxidation in alkaline solutions", Carbon, Vol. 47, No. 1, pp. 271-278, 2009

[32] R. N. Singh, T. Sharma, A. Singh, Anindita, D. Mishra, S. K. Tiwari, "Perovskite-type $\mathrm{La}_{2-\mathrm{x}} \mathrm{Sr}_{\mathrm{x}} \mathrm{NiO}_{4}(0 \leq \mathrm{x} \leq 1)$ as active anode materials for methanol oxidation in alkaline solutions", Electrochim. Acta, Vol. 53, No. 5, pp. 2322-2330, 2008

[33] Y. Zhao, L. Zhan, J. Tian, S. Nie, Z. Ning, "Enhanced electrocatalytic oxidation of methanol on $\mathrm{Pd} /$ polypyrrole-graphene in alkaline medium", Electrochim. Acta, Vol. 56, No. 5, pp. 1967-1972, 2011

[34] W. E. Mustain, J. Prakash, "Kinetics and mechanism for the oxygen reduction reaction on polycrystalline cobalt-palladium electrocatalysts in acid media", J. Power Sources, Vol. 170, No. 1, pp. 28-37, 2007

[35] S. M. Choi, M. H. Seo, H. J. Kim, W. B. Kim, "Synthesis of surfacefunctionalized graphene nanosheets with high Pt-loadings and their applications to methanol electrooxidation", Carbon, Vol. 49, No. 3, pp. 904-909, 2011

[36] J. J. Salvador-Pascual, S. Citalan-Cigarroa, O. Solorza-Feria, "Kinetics of oxygen reduction reaction on nanosized $\mathrm{Pd}$ electrocatalysts in acid media", J. Power Sources, Vol. 172, No. 1, pp. 229-234, 2007

[37] Madhu, R. N. Singh, "Palladium selenides as active methanol tolerant cathode materials for direct methanol fuel cell", Int. J. Hydrogen Energy, Vol. 36, No. 16, pp. 10006-10012, 2011

[38] R. Pattabiraman, "Electrochemical investigations on carbon supported palladium catalysts", Appl. Catal. A, Vol. 153, No. 1, pp. 9-20, 1997

[39] R. N. Singh, A. Singh, Anindita, "Electrocatalytic activity of binary and ternary composite films of Pd, MWCNT and Ni, Part II: methanol electrooxidation in $1 \mathrm{M} \mathrm{KOH",} \mathrm{Int.} \mathrm{J.} \mathrm{Hydrogen} \mathrm{Energy,} \mathrm{Vol.} \mathrm{34,} \mathrm{pp.}$ 2052-2057, 2009

[40] B. Hammer, J. K. Norskov, "Theoretical surface science and catalystcalculation concepts", Adv. Catal. Vol. 45, pp. 71-129, 2000
[41] N. M. Markovic, B. N. Grgur, P. N. Ross, "Temperature-dependent hydrogen electrochemistry on platinum low-index single-crystal surfaces in acid solutions", J. Phys. Chem. B, Vol. 101, No. 27, pp. 5405-5413, 1997

[42] J. X. Wang, S. R. Brankovic, Y. Zhu, J. C. Hanson, R. R. Adzic, "Kinetic characterization of PtRu fuel cell anode catalysts made by spontaneous Pt deposition on Ru nanoparticles", J. Electrochem. Soc. Vol. 150, No. 8, pp. A1108-A1117, 2003

[43] E. Gileadi, Electrode kinetics for Chemists, Chemical Engineers, and Materials Scientists, Wiley-VCH, 1993

[44] D. Yang, B. Li, H. Zhang, J. Ma, "Kinetics and electrocatalytic activity of $\mathrm{IrCo} / \mathrm{C}$ catalysts for oxygen reduction reaction in PEMFC", Int. J. Hydrogen Energy, Vol. 37, No. 3, pp. 2447-2454, 2012

[45] J. Zhang, Y. Mo, M. B. Vukmirovic, R. Klie, K. Sasaki, R. R. Adzic, "Platinum monolayer electrocatalysts for $\mathrm{O}_{2}$ reduction: Pt monolayer on $\mathrm{Pd}(111)$ and on carbon-supported Pd nanoparticles", J. Phys. Chem. B, Vol. 108, No. 30, pp. 10955-10964, 2004

[46] G. Ramos-Sanchez, O. Solorza-Feria, "Synthesis and characterization of $\mathrm{Pd}_{0.5} \mathrm{Ni}_{\mathrm{x}} \mathrm{Se}_{(0.5-\mathrm{x})}$ electrocatalysts for oxygen reduction reaction in acid media", Int. J. Hydrogen Energy, Vol. 35, No. 21, pp. 12105-12110, 2010

[47] R. Rego, M. Cristina Oliveira, F. Alcaide, G. Alvarez, "Development of a carbon paper-supported Pd catalyst for PEMFC application”, Int. J. Hydrogen Energy, Vol. 37, No. 8, pp. 7192-7199, 2012

[48] K. Jukk, N. Alexeyeva, C. Johans, K. Kontturi, K. Tammeveski, "Oxygen Reduction on Pd nanoparticle/multi-walled carbon nanotube composites", J. Electronal. Chem. Vol. 666, pp. 67-75, 2012 